\title{
Isolasi dan Karakterisasi Jamur Pendegradasi Katekin dari Seresah Pinus
}

\section{Isolation and Characterization of Catechin-Degrading Fungus from Pine Litter}

\author{
Elisa Nurnawati ${ }^{1}$ \& Langkah Sembiring ${ }^{2 *}$ \\ ${ }^{1}$ Jurusan Biologi FMIPA Universitas Sriwijaya Palembang \\ ${ }^{2}$ Laboratorium Mikrobiologi Fakultas Biologi UGM Jogjakarta, *korespondensi
}

\begin{abstract}
Isolation of catechin-degrading fungus from pine litter samples was done using minimal medium that containing catechin as sole carbon and energy source. A total of 53 isolates were chosen to represent different colonial types of catechin degrading-fungus. The isolates were screened for their ability to degrade catechin in three stages. The first stage of screening was based on their ability to grow on solid medium containing $2 \mathrm{mM}$, and as a result, 28 isolates were selected. The second stage of screening on the same medium but containing $4 \mathrm{mM}$ of catechin resulting in 14 selected isolates. The third stage screening was based on their mean growth rate constant $(k)$, instantaneous growth rate constant $(\mu)$ and generation time $(g)$ on minimal medium containing $4 \mathrm{mM}$ catechin. The result showed that four isolates (D9, K2, K11, and S11) were the best catechin degradator. Further growth kinetic study ( $k, \mu$, and $g$ ) of selected isolates indicated that D9, K2, and S11 grew well on the medium containing $40 \mathrm{mM}$, but K11 was inhibited by concentration of higher than $10 \mathrm{mM}$. Catechin biodegradation process was determined by following the decrease of catechin concentration on liquid medium. It was found that isolate K2 had higher ability to degrade catechin than the isolate K11. Finally, the four selected isolates from the third stage were characterized in terms of macroscopic, microscopic and phenotypic characters and identified. The result of the study showed that the isolates D9, $K 2$ and $S 11$ were identified as member of Aspergillus niger group. The isolate D9 was very similar to isolate S11, while the isolate K2 was found to be the most similar with Aspergillus niger van Tiegh. IFO 6341. The isolate K11 was assigned to be member of the genus Trichoderma.
\end{abstract}

Keywords : catechin biodegradation, pine litter, Aspergillus niger, Trichoderma $s p$

Diterima: 1 Oktober 2002, disetujui: 3 Mei 2003

\section{Pendahuluan}

Tumbuhan pinus (Pinus merkusii) banyak dikembangkan di Indonesia karena banyak manfaatnya sehingga seresah yang dihasilkan juga meningkat. Seresah pinus memiliki tingkat dekomposisi yang lebih lambat daripada seresah tumbuhan lain (Hardiwinoto et al., 1994), misalnya seresah Pinus sylvestris L. memerlukan waktu 9 tahun untuk menjadi humus (Kendrick, 2000). Hal ini disebabkan oleh perbedaan komposisi senyawa kimia daun (Williams \& Gay, 1974) padahal nutrisi tumbuhan hutan berasal dari dekomposisi seresah di lantai hutan.

Senyawa kompleks penyusun bahan organik tumbuhan, di antaranya tanin, sering memperlambat proses dekomposisi. Tanin merupakan senyawa polifenol alami yang ditemukan pada Pinus sp dengan kandungan yang tinggi terutama tanin terkondensasi (Bhat et al., 1998). Tanin jenis ini sulit didegradasi, sehingga bila konsentrasinya dalam bahan organik tinggi akan memperlambat dekomposisi (William \& Gay, 1974). Tanin terkondensasi merupakan polimer katekin (termasuk senyawa flavonoid). Katekin pada konsentrasi 
di atas $50 \mathrm{mM}$ bersifat toksik terhadap Bradyrhizobium japonicum, tetapi pada konsentrasi $0,5-5 \mathrm{mM}$ dapat meningkatkan pertumbuhan Bradyrhizobium japonicum (Hopper \& Mahadevan, 1991). Katekin juga resisten terhadap pemecahan oleh bakteri dari usus manusia (Winter et al., 1989). Beberapa mikrobia di antaranya Rhizobium sp., B. japonicum, Aspergillus sp. dan Fusarium sp. dapat menggunakan katekin sebagai satu-satunya sumber karbon dan energi (Muthukumar et al., 1982; Mahadevan \& Sivaswamy, 1985; Gajendiran \& Mahadevan, 1988; Hopper \& Mahadevan, 1991).

Seresah di lantai hutan merupakan lingkungan yang cocok bagi pertumbuhan mikrobia heterotrof termasuk jamur. Peran utama jamur tanah adalah sebagai dekomposer bahan organik. Menurut Brady (1985), jamur merupakan mikrobia dominan pada tanah asam karena bakteri dan actinomycetes sangat lemah kemampuannya berkompetisi pada tanah tersebut. Oleh karena itu, pada daerah yang mempunyai $\mathrm{pH}$ asam, jamur lebih efektif dalam mendegradasi bahan organik daripada bakteri. Keberadaan jamur di lantai hutan sangat penting untuk berlangsungnya proses transformasi unsur. Penelitian ini bertujuan untuk memperoleh jamur pendegradasi katekin dari seresah di lantai hutan pinus dan mempelajari aktivitas serta karakteristiknya.

\section{Metode Penelitian}

\section{Pengambilan Sampel}

Seresah Pinus merkusii diperoleh di lantai hutan pinus RPH Kaliurang Petak 7e (Kalikuning, Cangkringan, Sleman), daerah Sermo RPH Bantar (Kokap, Kulon Progo) dan RPH Mangunan Dlingo, Bantul sebagai sumber isolat jamur. Seresah berwarna coklatkehitaman dan terpotong-potong yang berada di bawah lapisan segar diambil pada beberapa titik di lantai hutan pinus. Seresah yang diperoleh diamati ciri fisik secara kualitatif (kondisi fisik, kemurnian seresah, warna, dan kekerasan) dan ciri kimia secara kuantitatif (kadar air, $\mathrm{pH}$, dan nisbah C:N).
Isolasi jamur pengguna katekin.

Isolasi jamur dilakukan dengan metode spread plate pada medium minimal (Hussien dkk., 1974) ditambah katekin sampai konsentrasi $2 \mathrm{mM}$ dan kloramfenikol $200 \mathrm{mg} / \mathrm{l}$. Inkubasi dilakukan pada suhu kamar. Koloni jamur yang tumbuh diisolasi dan disubkultur sampai koloni yang diperoleh benar-benar murni. Koloni yang diperoleh dikarakterisasi awal secara makroskopik.

Seleksi isolat jamur pengguna katekin.

Semua isolat jamur diuji pertumbuhannya pada medium minimal dengan sumber karbon satu-satunya adalah katekin. Untuk menyeragamkan jumlah inokulum awal dilakukan perhitungan jumlah spora dilakukan pada biakan jamur berumur 6 hari dengan menggunakan hemasitometer. Seleksi tahap pertama dilakukan dengan mengamati pertumbuhan dalam medium minimal padat yang mengandung $2 \mathrm{mM}$ katekin. Kerapatan inokulum adalah $10^{7}$ spora $/ \mathrm{ml}$ dan inkubasi pada suhu kamar selama 4 hari. Pengamatan dilakukan secara kualitatif, isolat jamur yang mampu tumbuh paling banyak dan menyebar yang dipilih untuk seleksi selanjutnya. Seleksi kedua dilakukan dengan metode seperti seleksi pertama dengan konsentrasi katekin dalam medium sebesar $4 \mathrm{mM}$. Seleksi ketiga dilakukan dengan mengukur pertambahan diameter koloni isolat jamur terpilih pada medium minimal padat yang mengandung 4 $\mathrm{mM}$ katekin, inkubasi selama 14 hari pada suhu kamar. Jumlah inokulum sama, diambil sebanyak $20 \mu \mathrm{l}$ dan diteteskan di tengah-tengah medium.

Uji kemampuan isolat jamur pengguna katekin dalam medium padat yang mengandung katekin dengan konsentrasi bervariasi.

Keempat isolat jamur terpilih dilihat kemampuannya menggunakan katekin pada konsentrasi 10, 20, 30, dan $40 \mathrm{mM}$ dalam medium minimal padat. Parameter kinetika pertumbuhan $(\mathrm{k}, \mu$, dan $\mathrm{g})$ ditentukan dengan 
pengukuran diameter koloni setiap 24 jam selama 14 hari.

Uji kemampuan isolat jamur mendegradasi katekin dalam medium cair.

Isolat jamur terpilih diuji kemampuannya mendegradasi katekin dalam medium cair dengan konsentrasi $20 \mathrm{mM}$. Pengamatan dilakukan pada hari ke-0, 7, 14, dan 21. Sampel dipisahkan dari miselium jamurnya dengan cara disaring. Miselium jamur yang telah terpisah dengan medium dikeringkan untuk mengetahui biomassa jamur. Cairan medium diekstraksi dengan $20 \mathrm{ml}$ etil asetat, kemudian diuapkan dengan vacuum evaporator. Residu dianalisis dengan HPLC (Perkin Elmer series 200 lc pump) fase balik untuk melihat penurunan konsentrasi katekin. Cuplikan sebanyak 20ul diinjeksikan dan pemisahan senyawa dilakukan dengan menggunakan kolom CLC-ODS (4,6 mm x $250 \mathrm{~mm})$ dengan fase gerak campuran asetonitril:air (7:3 v/v) berkecepatan alir $1 \mathrm{ml} / \mathrm{menit}$. Deteksi dilakukan dengan detektor UV/VIS (Perkin Elmer LC 295) pada panjang gelombang 280 $\mathrm{nm}$. Sampel dan standar dilarutkan dalam pelarut yang sama.

Karakterisasi dan identifikasi isolat jamur.

Isolat jamur terpilih dikarakterisasi meliputi karakter makroskopis, mikroskopis dan fenotipik berupa kemampuan asimilasi substrat (Patterson \& Bridge, 1994). Identifikasi dilakukan dengan metode profile matching dibandingkan dengan strain acuan.

\section{Hasil}

Sifat fisikokimiawi dan mikrobiawi sampel seresah.

Sumber isolat adalah seresah pinus dari hutan pinus di Kalikuning, Sermo, dan Dlingo yang masing-masing memiliki karakteristik fisik dan kimia pada tanah dan seresahnya (Tabel 1).
Isolasi jamur pendegradasi katekin.

Isolasi jamur pengguna katekin dari tiga lokasi menghasilkan 53 tipe isolat. Semua isolat dikelompokkan berdasarkan kenampakan makroskopisnya menjadi 13 kelompok isolat (Tabel 2). Kelompok isolat kapang mempunyai distribusi yang berbeda (Tabel 3). Lokasi Kalikuning dan Sermo mengandung isolat jamur pendegradasi katekin lebih bervariasi dari pada Dlingo. Pada kedua lokasi tersebut jumlah total isolat jamur juga lebih banyak daripada Dlingo.

Seleksi kemampuan isolat jamur menggunakan katekin.

Semua isolat jamur yang diperoleh diuji pertumbuhannya pada medium minimal padat dengan sumber karbon satusatunya adalah katekin.

Pada seleksi pertama diperoleh 28 tipe isolat jamur yang mampu tumbuh lebih baik dari total 53 tipe isolat (Tabel 4). Isolat jamur yang diperoleh dari seleksi pertama diamati kembali pertumbuhannya dalam medium minimal yang mengandung $4 \mathrm{mM}$ katekin. Pengamatan sama dengan seleksi pertama. Dari 28 isolat, hanya 14 isolat yang mampu tumbuh baik (Tabel 5).

Seleksi terakhir menghasilkan 4 isolat jamur dengan nilai konstanta kecepatan pertumbuhan spesifik $(\mu)$ tertinggi (Gambar 1). Keempat isolat terpilih tersebut adalah K2 dan K11 dari Kalikuning, S11 dari Sermo dan D9 dari Dlingo.

Uji kemampuan isolat jamur terpilih dalam konsentrasi katekin yang bervariasi.

Hasil pengujian (Gambar 2) menunjukkan bahwa isolat D9, S11 dan K2 mampu menggunakan katekin sebagai satusatunya sumber karbon. Konsentrasi katekin sampai $40 \mathrm{mM}$ tidak mempengaruhi pertumbuhannya. 
Pertumbuhan isolat K11 terbaik pada konsentrasi katekin $10 \mathrm{mM}$, dengan meningkatnya konsentrasi pertumbuhan isolat K11 makin terhambat (Gambar 2d).

Uji kemampuan isolat jamur mendegradasi katekin.

Isolat jamur K2 dan K11 diamati kemampuannya dalam mendegradasi katekin. Isolat $\mathrm{K} 2$ dipilih karena pada seleksi ketiga isolat $\mathrm{K} 2$ mempunyai nilai $\mu$ terbesar, sedangkan isolat $\mathrm{K} 11$ merupakan anggota genus lain. Isolat $\mathrm{K} 2$ mampu tumbuh dengan baik dan mencapai akhir fase logaritmik pada hari ke-7 (Gambar 3a), sedangkan pada saat yang sama isolat K11 masih mengalami fase lag. Kemampuan kedua isolat dalam menurunkan konsentrasi katekin tidak terlalu besar karena pada hari ke-21 masih ditemukan adanya katekin, selain itu proses biodegradasi diikuti oleh proses non-biotik.

Karakterisasi dan identifikasi isolat jamur terpilih.

Karakterisasi dan identifikasi dilakukan terhadap empat isolat terpilih yaitu D9, K2, K11, dan S11. Berdasarkan kenampakan makroskopis, ketiga isolat terpilih dari masing-masing lokasi sampling yaitu $\mathrm{K} 2$, S11, dan D9 merupakan tipe isolat dari satu kelompok (Tabel 3) dengan ciri khas koloni tertutup spora coklat sampai hitam pekat. Di antara ketiga isolat tersebut ada perbedaan warna koloni yaitu isolat K2 berwarna hitam pekat dan isolat D9 sama dengan S11 yaitu coklat tua pada medium PDA. Warna koloni strain acuan (Aspergillus niger van Tiegh. IFO 6341) sama dengan isolat $\mathrm{K} 2$, hitam pekat. Dengan demikian isolat kelompok 2 ini diduga merupakan kelompok Aspergillus niger (Rapper \& Fennel, 1977).

Isolat K11 merupakan tipe isolat kelompok 3 (Tabel 3) dengan ciri khas koloni putih berspora hijau. Berdasarkan pengamatan mikroskopis, isolat $\mathrm{K} 11$ diduga merupakan anggota kelompok
Trichoderma sp. karena mempunyai konidiofor bercabang menyerupai piramida (pada bagian bawah bercabang lateral yang berulang, sedang ke arah ujung percabangan menjadi lebih pendek) (Samson et al., 1995). Hasil karakterisasi fenotipik menunjukkan ada perbedaan antara masing-masing isolat jamur (Tabel 6 dan 7).

\section{Pembahasan}

Isolasi jamur pendegradasi katekin dari seresah pinus telah dilakukan dengan menggunakan medium selektif yang mengandung katekin sebagai satu-satunya sumber karbon dan energi. Seresah pinus yang berasal dari lokasi yaitu Kalikuning, Sermo dan Dlingo mempunyai karakter seresah yang berbeda (Tabel 1). Seresah pinus dari Kalikuning mempunyai kadar air lebih tinggi daripada seresah dari lokasi lain. Perbedaan karakter habitat ini diperkirakan mempengaruhi jumlah dan tipe isolat jamur yang ditemukan. Menurut Coyne (1999), jamur memerlukan lingkungan tumbuh lembab. Karakter lain yaitu $\mathrm{pH}$ seresah dan nisbah $\mathrm{C} / \mathrm{N}$ seresah pinus ketiga lokasi tidak agak mirip sehingga mungkin hal tersebut tidak mempengaruhi kerapatan propagul. Tipe hutan berbeda menghasilkan seresah yang berbeda pula. Hal ini sesuai dengan hasil penelitian Christensen dan Wittingham 1965 cit. Cooke (1979) yang menunjukkan bahwa komposisi jenis dalam komunitas jamur berkorelasi dengan jenis tumbuhan di atasnya

Menurut hasil penelitian yang diperoleh dari Anonim (1999) tanah di Sermo dan Dlingo mempunyai tekstur liat bersifat lekat dan agak basah akan membentuk struktur kompak sehingga pori sedikit, sedangkan tanah di Kalikuning bertekstur pasir halus dan tidak lekat. Porositas tanah yang tidak baik kurang mendukung pertumbuhan jamur karena jamur bersifat aerob obligat. Bahan induk tanah di Kalikuning merupakan bahan volkan yang diperkirakan mengandung nutrien yang lebih tinggi daripada tanah di Sermo dan Dlingo (breksi andesit dan batu 
gamping). Perbedaan karakter tanah ini diperkirakan mempengaruhi kerapatan propagul jamur karena menurut Kendrick (2000), jamur dapat daun tumbuhan penutup maupun dari tanah. Apabila dilihat dari beberapa karakter tersebut nampak bahwa lokasi Kalikuning lebih cocok untuk pertumbuhan jamur sehingga kerapatan propagul jamur pada seresah pinus dari Kalikuning lebih besar dan paling sedikit pada seresah pinus dari Dlingo.

Seleksi kemampuan isolat jamur dalam menggunakan katekin menghasilkan 4 isolat terpilih yaitu K2 dan K11 dari Kalikuning, S11 dari Sermo dan D9 dari Dlingo. Isolat K2, S11, dan D9 mampu tumbuh dengan baik pada katekin sampai konsentrasi $40 \mathrm{mM}$, sedangkan konsentrasi katekin di atas $10 \mathrm{mM}$ mungkin toksik bagi isolat K11. Berdasarkan analisis penurunan konsentrasi katekin (Gambar 3), isolat K2 $(\mu=8,556)$ lebih cepat daripada isolat $\mathrm{K} 11$ $(\mu=7,174)$. Pada analisis ini nampak bahwa katekin juga mengalami degradasi nonbiotik walaupun jauh lebih lambat daripada degadasi biotik.

Berdasarkan karakteristik makroskopis, mikroskopis dan fenotipik, isolat D9, S11, dan K2 diidentifikasi sebagai anggota spesies Aspergillus niger. Kelompok jamur ini merupakan jamur yang bersifat ubiquitous (Klich et al., 1992). Isolat K11 didentifikasi sebagai anggota genus Trichoderma. Anggota genus ini mudah ditemui di tanah dan sebagai dekomposer kayu. Kedua genera (Aspergillus dan Trichoderma) ini mempunyai kisaran substrat yang luas (Samson et al., 1995). Penggabungan karakter mikroskopis dengan karakter kultur menunjukkan bahwa isolat D9 diduga sangat mirip dengan isolat $\mathrm{S} 11$ sedangkan isolat $\mathrm{K} 2$ lebih mirip dengan Aspergillus niger van Tiegh. IFO 6341. Isolat K11 adalah anggota genus Trichoderma, tetapi ada perbedaan yang cukup besar antara isolat K11 dengan Trichoderma viride Pers. CBS 189.79, sehingga isolat $\mathrm{K} 11$ diduga merupakan anggota spesies lain dalam genus Trichoderma.

\section{Kesimpulan}

Jamur pengguna katekin dapat diisolasi dari seresah pinus yang berasal dari Kalikuning, Sermo dan Dlingo sebanyak 53 tipe isolat. Empat isolat yaitu D9, K2, K11 dan S11 merupakan tipe isolat terpilih. Isolat jamur D9, S11 dan K2 diidentifikasi sebagai anggota kelompok Aspergillus niger. Isolat jamur K11 merupakan anggota genus Trichoderma tetapi bukan Trichoderma viride Pers. CBS 189.79. Katekin dapat dide-gradasi oleh isolat K2 (Aspergillus niger) lebih cepat dari pada isolat K11 (Trichoderma sp.). Hasil penelitian ini juga menunjukkan bahwa katekin dapat juga mengalami degradasi non-biotik walaupun jauh lebih lambat. 


\section{Daftar Pustaka}

Anonim . 1999. BPTP Daerah Istimewa Jogjakarta

Bhat, T.K., B. Singh \& O.P. Sharma. 1998. Microbial degadation of tannins: a current perspective. Biodeg. 9 : 343-357

Brady, N.C. 1985. The Nature and properties of Soil. Mac-Milan Publishing Company. Philiphina.

Cooke, W.B. 1979. The Ecology of Fungi. CRC Press. Boca Raton.

Coyne, M.S. 1999. Soil Microbiology: An Exploratory Approach. Delmar Pub. Boston.

Gajendiran, N \& A. Mahadevan. 1988. Utilization of catechin by Rizhobium sp. Plant Soil. 108 :263-266.

Hardiwinoto, S; H. Supriyo; F. Mangkuwibowo \& S. Sabarnuddin. 1994. Pengaruh sifat kimia terhadap tingkat dekomposisi beberapa jenis daun tanaman hutan. Manusia dan Lingkungan. 4:25-36.

Hopper, W \& A. Mahadevan. 1991. Utilization of catechin and its metabolites by Bradyrhizobium japonicum. Appl. Microbiol. Biotechnol. 35 : 411-415.

Hopper, W. \& A. Mahadevan. 1997. Degradation of catechin by Bradyrhizobium japonicum. Biodeg. 8 : 159-165.

Hussien, Y.A., M.S. Tewfik \& Y.A. Hamdi. 1974. Degradation of certain aromatic compounds by rhizobia. Soil. Biol. Biochem. 2:377-381.

Kendrick, B. 2000. Fungal Ecology: Fungal succesion in decomposition pine scot needle (Pinus sylvestris). In : Kendrick, B. (Ed.) The Fifth Kingdom $3^{\text {rd }}$ ed. Mycologue Publications. New York.
Klich, M.A., L.H. Tiffany \& G. Knaphus. 1992. Ecology of the Aspergilli of soils \&litter. In: Bennet, J.W. \& M.A. Klich (Eds.). Aspergillus: Biology and Industrial applications. 329-353. ButterwothHeinemann. Boston.

Mahadevan, A. \& S.N. Sivaswamy. 1985. Tannins and microorganisms. In: Mukerje, K.G., N.C. Pathak \& V.P. Singh (Eds.) Frontiers in applied microbiology. I : 327-347. Print House. India.

Muthukumar, G., A. Arunakumari \& A. Mahadevan. 1982. Degadation of aromatic compounds by Rhizobium spp. Plant Soil. 69 : 163-169.

Patterson, R.R.M. \& D.P. Bridge. 1994. Biochemical Techniques for Filamentous Fungi. CAB International. Oxon.

Rapper, K.B. \& D. I. Fennel. 1977. The Genus Aspergillus. Robert E. Krieger Pub. Company. New York.

Samson, R.A., E.S. Hoekstra., J.C. Frisvad \& O. Filtenborg. 1995. Methods for detection and isolation of food-borne fungi. In: Samson, R.A., E.S. Hoekstra., J.C. Frisvad \& O. Filtenborg (Eds.). Introduction to food-borne fungi. Centraalbureau voor Schimmencultures. Baarn.

William, S.T. \& T.R.G. Gay. 1974. Decomposition of coniferous leaf litter. In: Dickinson, C.H. \& G.J.F. Pugh. (Eds.) Biology of plant litter decomposition. 1: 105-128.

Winter. J., L.H. Moore, V.R. Dowell, Jr. \& V.D. Bokkenheuser. 1989. C-ring cleavage of flavonoids by human intestinal bacteria. Appl. Environ. Microbiol. 55 : 1203-1208 
Tabel 1. Karakter fisikokimia dan mikrobiologi seresah pinus yang diperoleh dari Kalikuning, Sermo dan Dlingo.

\begin{tabular}{|c|c|c|c|c|}
\hline & Sampel & Kali Kuning, Sleman & Sermo, Kulon Progo & Dlingo, Bantul \\
\hline 1. & Kondisi fisik & $\begin{array}{l}\text { Seresah berwarna coklat hitam } \\
\text { terkolonisasi jamur, terpotong- } \\
\text { potong dan sedikit tercampur } \\
\text { dengan tanah (warna hitam). }\end{array}$ & $\begin{array}{l}\text { Seresah berwarna coklat terko- } \\
\text { lonisasi jamur, agak terpotong- } \\
\text { potong, bercampur dengan tanah } \\
\text { (warna coklat) dan seresah relatif } \\
\text { lebih kering. }\end{array}$ & $\begin{array}{l}\text { Seresah berwarna coklat lebih } \\
\text { banyak yang terkolonisasi oleh } \\
\text { jamur, bercampur dengan tanah } \\
\text { (warna merah), agak terpotong- } \\
\text { potong dan relatif lebih kering. }\end{array}$ \\
\hline 2. & $\begin{array}{l}\text { Homogenitas } \\
\text { seresah }\end{array}$ & $\begin{array}{l}\text { Agak homogen, vegetasi hutan } \\
\text { sedikit tercampur pohon lain. }\end{array}$ & $\begin{array}{l}\text { Heterogen, vegetasi hutan pinus } \\
\text { tercampur tumbuhan lain }\end{array}$ & Homogen \\
\hline 3. & Warna & Coklat hitam & Coklat & Coklat \\
\hline 4. & Kekerasan & Rapuh & Agak liat & Agak liat \\
\hline 5. & Kadar air $(\%)$ & 71,25 & 43 & 26,23 \\
\hline 6. & Keasaman $(\mathrm{pH})$ & 5,85 & 5,42 & 5,28 \\
\hline 7. & Kadar C (\%) & 42,08 & 44,52 & 49,87 \\
\hline 8. & Kadar N (\%) & 0,270 & 0,273 & 0,289 \\
\hline 9. & Nisbah C:N & 155,85 & 163,08 & 172,56 \\
\hline 10. & $\begin{array}{l}\text { Jumlah jamur } \\
\text { (cfu/g-berat } \\
\text { kering) }\end{array}$ & $11,77 \times 10^{4}$ & $5,94 \times 10^{4}$ & $3,97 \times 10^{4}$ \\
\hline 11. & $\begin{array}{l}\text { Jumlah tipe } \\
\text { isolat jamur }\end{array}$ & 18 & 21 & 14 \\
\hline
\end{tabular}

Tabel 2. Pengelompokan isolat berdasarkan ciri morfologi makroskopis

\begin{tabular}{|c|c|c|c|c|}
\hline \multirow{2}{*}{$\begin{array}{l}\text { Kel. } \\
\text { Isolat }\end{array}$} & \multicolumn{2}{|c|}{ Morfologi koloni (inkubasi 1 minggu pada suhu kamar) } & \multirow{2}{*}{ Kode isolat * } & \multirow{2}{*}{$\begin{array}{c}\text { Jumlah } \\
\text { Anggota } \\
\text { isolat }\end{array}$} \\
\hline & Medium minimal & Potato Dekstrosa Agar (PDA) & & \\
\hline 1.1. & $\begin{array}{l}\text { Spora hijau, koloni tipis hifa } \\
\text { putih, medium sekitar koloni } \\
\text { menjadi kuning. }\end{array}$ & $\begin{array}{l}\text { Koloni tertutup spora hijau tua, } \\
\text { medium sekitar koloni menjadi } \\
\text { coklat }\end{array}$ & $(\mathrm{K} 1, \mathrm{~S} 1, \mathrm{~S} 2, \mathrm{D} 1)$ & 4 \\
\hline 1.2 . & $\begin{array}{l}\text { Spora hijau, koloni tipis, hifa } \\
\text { putih, medium sekitar koloni } \\
\text { menjadi kuning }\end{array}$ & $\begin{array}{l}\text { Koloni tertutup spora hijau, medium } \\
\text { sekitar koloni tetap putih. }\end{array}$ & (D11, D12) & 2 \\
\hline 2 & $\begin{array}{l}\text { Spora hitam, koloni tipis, } \\
\text { medium sekitar koloni menjadi } \\
\text { kuning tua }\end{array}$ & $\begin{array}{l}\text { Koloni tertutup spora hitam tumbuh } \\
\text { cepat, menyebar lebat menutup } \\
\text { permukaan medium }\end{array}$ & (K2, S11, D9) & 3 \\
\hline 3 & $\begin{array}{l}\text { Spora hijau, koloni tipis } \\
\text { menyebar, hifa putih }\end{array}$ & $\begin{array}{l}\text { Koloni menyebar cepat, lebat, } \\
\text { tertutup spora hijau dengan } \\
\text { permukaan agak basah }\end{array}$ & $\begin{array}{l}\text { (D2,D3,D4,D5,D7,D8,D13, } \\
\text { S3,S4,S5,S6,S8,S9,S10, } \\
\text { K4,K5,K6,K8,K9, } \\
\text { K10,K11,K12,K13,K14,K16) }\end{array}$ & 25 \\
\hline 4.1 & $\begin{array}{l}\text { Hifa putih, medium sekitar } \\
\text { koloni menjadi coklat }\end{array}$ & $\begin{array}{l}\text { Hifa putih medium sekitar koloni } \\
\text { menjadi medium hitam }\end{array}$ & $(\mathrm{S} 17, \mathrm{~S} 19, \mathrm{D} 10, \mathrm{D} 14)$ & 4 \\
\hline 4.2 & $\begin{array}{l}\text { Hifa putih, medium sekitar } \\
\text { koloni menjadi kuning }\end{array}$ & $\begin{array}{l}\text { Hifa kelabu menggunung dan } \\
\text { berserabut, medium sekitar koloni } \\
\text { menjadi medium kuning-coklat }\end{array}$ & (K7) & 1 \\
\hline 5.1 & $\begin{array}{l}\text { Koloni transparan, medium } \\
\text { sekitar koloni menjadi kuning- } \\
\text { coklat }\end{array}$ & Hifa tipis putih kekuningan & (K15, S14, S15, S20) & 4 \\
\hline 5.2 & $\begin{array}{l}\text { Koloni putih, berspora agak } \\
\text { krem, medium sekitar koloni } \\
\text { menjadi kuning-coklat }\end{array}$ & $\begin{array}{l}\text { Hifa putih tertutup spora berwarna } \\
\text { merah kelabu }\end{array}$ & $(\mathrm{S} 12, \mathrm{~S} 16)$ & 2 \\
\hline
\end{tabular}


Tabel 2. (lanjutan)

\begin{tabular}{|c|c|c|c|c|}
\hline \multirow{2}{*}{$\begin{array}{l}\text { Kel. } \\
\text { Isolat }\end{array}$} & \multicolumn{2}{|c|}{ Morfologi koloni (inkubasi 1 minggu pada suhu kamar) } & \multirow{2}{*}{ Kode isolat * } & \multirow{2}{*}{$\begin{array}{l}\text { Jumlah } \\
\text { Anggota } \\
\text { isolat }\end{array}$} \\
\hline & Medium minimal & Potato Dekstrosa Agar (PDA) & & \\
\hline 5.3 & $\begin{array}{l}\text { Hifa putih tumbuh ke atas, } \\
\text { medium sekitar koloni menjadi } \\
\text { kuning }\end{array}$ & $\begin{array}{l}\text { Hifa putih menyebar medium sekitar } \\
\text { koloni menjadi kuning dengan ujung } \\
\text { hifa hitam }\end{array}$ & $(\mathrm{S} 7, \mathrm{D} 6)$ & 2 \\
\hline 5.4 & $\begin{array}{l}\text { Koloni putih menyebar spora } \\
\text { putih di tepi koloni }\end{array}$ & $\begin{array}{l}\text { Hifa putih, spora putih, medium } \\
\text { sekitar koloni menjadi medium } \\
\text { berwarna merah }\end{array}$ & (K17) & 1 \\
\hline 6.1 & Hifa transparan & $\begin{array}{l}\text { Hifa putih membentuk lingkaran } \\
\text { konsentris }\end{array}$ & $(\mathrm{S} 13, \mathrm{~S} 18, \mathrm{~S} 21)$ & 3 \\
\hline 6.2 & Hifa transparan & Hifa transparan menyebar & (K3) & 1 \\
\hline \multirow[t]{2}{*}{6.3} & Hifa putih transparan & Hifa putih menggunung & $(\mathrm{K} 18)$ & 1 \\
\hline & & & Jumlah total & 53 \\
\hline
\end{tabular}

Tabel 3. Distribusi tipe isolat jamur yang diperoleh dari masing-masing lokasi penelitian

\begin{tabular}{|c|c|c|}
\hline Lokasi & Jumlah tipe isolat & Total isolat \\
\hline Kalikuning & 8 & 18 \\
\hline Sermo & 8 & 21 \\
\hline \multirow[t]{2}{*}{ Dlingo } & 6 & 14 \\
\hline & Total & 53 \\
\hline
\end{tabular}

Tabel 4. Hasil seleksi pertumbuhan isolat jamur dalam medium minimal padat yang mengandung $2 \mathrm{mM}$ katekin (inokulum $10^{7}$ spora/ml, inkubasi 4 hari, suhu kamar)

\begin{tabular}{|c|c|c|c|c|c|c|c|c|}
\hline \multicolumn{3}{|c|}{ Dlingo } & \multicolumn{3}{|c|}{ Sermo } & \multicolumn{3}{|c|}{ Kalikuning } \\
\hline \multirow{2}{*}{ Kode isolat } & \multicolumn{2}{|c|}{ Ulangan } & \multirow{2}{*}{ Kode isolat } & \multicolumn{2}{|c|}{ Ulangan } & \multirow{2}{*}{ Kode isolat } & \multicolumn{2}{|c|}{ Ulangan } \\
\hline & 1 & 2 & & 1 & 2 & & 1 & 2 \\
\hline D1 & +++ & +++ & S1 & +++ & +++ & K1 & +++ & +++ \\
\hline D2 & ++ & + & S2 & +++ & +++ & $\mathrm{K} 2$ & +++ & +++ \\
\hline D3 & ++ & ++ & S3 & +++ & +++ & $\mathrm{K} 3$ & + & + \\
\hline D4 & +++ & + & S4 & +++ & +++ & K4 & + & ++ \\
\hline D5 & + & + & S5 & ++ & + & K5 & ++ & ++ \\
\hline D6 & +++ & +++ & S6 & - & - & K6 & ++ & + \\
\hline D7 & ++ & ++ & S7 & +++ & +++ & K7 & +++ & +++ \\
\hline D8 & ++ & +++ & S8 & ++ & + & K8 & +++ & +++ \\
\hline D9 & +++ & +++ & S9 & + & ++ & K9 & ++ & ++ \\
\hline D10 & +++ & +++ & S10 & + & + & K10 & +++ & ++ \\
\hline D11 & +++ & +++ & S11 & +++ & +++ & K11 & +++ & +++ \\
\hline D12 & +++ & +++ & S12 & +++ & ++ & K12 & +++ & +++ \\
\hline D13 & ++ & + & S13 & +++ & +++ & K13 & ++ & ++ \\
\hline \multirow[t]{8}{*}{ D14 } & +++ & +++ & S14 & +++ & +++ & K14 & +++ & +++ \\
\hline & & & S15 & +++ & +++ & K15 & ++ & ++ \\
\hline & & & S16 & +++ & +++ & K16 & + & ++ \\
\hline & & & S17 & +++ & +++ & K17 & +++ & +++ \\
\hline & & & S18 & +++ & ++ & K18 & +++ & +++ \\
\hline & & & S19 & +++ & +++ & & & \\
\hline & & & S20 & + & + & & & \\
\hline & & & S21 & + & + & & & \\
\hline
\end{tabular}

Keterangan: +: tumbuh sdikit; ++: tumbuh agak lebat; +++: tumbuh lebat 
Tabel 5. Hasil seleksi pertumbuhan isolat jamur pada medium minimal padat yang mengandung $4 \mathrm{mM}$ katekin (inokulum $10^{7}$ spora/ml, inkubasi 4 hari, suhu kamar)

\begin{tabular}{|c|c|c|c|c|c|c|c|c|}
\hline \multicolumn{3}{|c|}{ Dlingo } & \multicolumn{3}{|c|}{ Sermo } & \multicolumn{3}{|c|}{ Kalikuning } \\
\hline \multirow{2}{*}{ Kode isolat } & \multicolumn{2}{|c|}{ Ulangan } & \multirow{2}{*}{ Kode isolat } & \multicolumn{2}{|c|}{ Ulangan } & \multirow{2}{*}{ Kode isolat } & \multicolumn{2}{|c|}{ Ulangan } \\
\hline & 1 & 2 & & 1 & 2 & & 1 & 2 \\
\hline 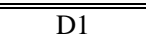 & ++++ & +++ & S1 & ++++ & ++++ & K1 & "+++ & ++++ \\
\hline D6 & ++ & ++ & $\mathrm{S} 2$ & +++ & +++ & $\mathrm{K} 2$ & +++ & +++ \\
\hline D9 & +++ & +++ & S3 & + & + & K7 & ++ & + \\
\hline D10 & ++ & ++ & S4 & + & ++ & K8 & ++ & ++ \\
\hline D11 & +++ & +++ & S7 & ++ & ++ & K11 & +++ & +++ \\
\hline D12 & +++ & +++ & S11 & +++ & +++ & K12 & ++ & + \\
\hline \multirow[t]{6}{*}{ D14 } & ++ & ++ & S13 & ++ & ++ & K14 & ++ & + \\
\hline & & & S14 & +++ & +++ & K17 & +++ & +++ \\
\hline & & & S15 & +++ & +++ & K18 & ++ & ++ \\
\hline & & & S16 & +++ & +++ & & & \\
\hline & & & S17 & ++ & ++ & & & \\
\hline & & & S19 & ++ & +++ & & & \\
\hline
\end{tabular}

Keterangan : +: pertumbuhan sedikit; ++: pertumbuhan agak lebat; +++: tumbuh lebat

Tabel 6. Karakteristik kultur dan pertumbuhan isolat jamur dan strain referensi

\begin{tabular}{|c|c|c|c|c|}
\hline Nama jamur & $\begin{array}{c}\text { Karakteristik kultur dan } \\
\text { pertumbuhan }\end{array}$ & $\begin{array}{l}\text { Potato dextrosa agar } \\
\text { (PDA) }\end{array}$ & Czapek dox agar & $\begin{array}{l}\text { Malt extract agar } \\
\text { (MEA) }\end{array}$ \\
\hline Aspergillus niger van & - Pertumbuhan & +++ & ++ & +++ \\
\hline \multirow[t]{2}{*}{ Tiegh IFO 6341} & - warna koloni & hitam pekat & hitam pekat & hitam pekat \\
\hline & - warna medium sekitar koloni & Putih (tidak berubah) & Putih (tidak berubah) & menjadi kuning tua \\
\hline Trichoderma viride & - Pertumbuhan & ++ & + & ++ \\
\hline \multirow[t]{3}{*}{ CBS 189.79} & - warna koloni & putih berspora hijau & putih spora hijau & putih spora hijau \\
\hline & - warna medium sekitar koloni & Putih (tidak berubah) & Putih (tidak berubah) & putih (tidak berubah) \\
\hline & - Pertumbuhan & +++ & +++ & +++ \\
\hline \multirow[t]{2}{*}{ D9 } & - warna koloni & coklat kehitaman & coklat tua & coklat kehitaman \\
\hline & $\begin{array}{l}\text { - warna medium sekitar koloni } \\
\text { - Pertumbuhan }\end{array}$ & $\begin{array}{l}\text { menjadi kekuningan } \\
+++\end{array}$ & $\begin{array}{l}\text { menjadi kuning } \\
+++\end{array}$ & $\begin{array}{l}\text { menjadi kuning muda } \\
+++\end{array}$ \\
\hline \multirow[t]{3}{*}{ S11 } & - warna koloni & coklat kehitaman & coklat tua & coklat kehitaman \\
\hline & - warna medium sekitar koloni & menjadi kekuningan & menjadi kuning & menjadi kuning \\
\hline & - Pertumbuhan & +++ & ++ & +++ \\
\hline \multirow[t]{3}{*}{$\mathbf{K} 2$} & - warna koloni & hitam pekat & hitam pekat & hitam pekat \\
\hline & - warna medium sekitar koloni & Putih (tidak berubah) & Putih (tidak berubah) & putih (tidak berubah) \\
\hline & - Pertumbuhan & +++ & & +++ \\
\hline \multirow[t]{2}{*}{ K11 } & - warna koloni & putih berspora hijau & putih berspora hijau & putih berspora hijau \\
\hline & - warna medium sekitar koloni & Putih (tidak berubah) & Putih (tidak berubah) & putih (tidak berubah) \\
\hline
\end{tabular}

Keterangan : + : pertumbuhan sedikit ;, ++: pertumbuhan agak lebat; +++: pertumbuhan lebat 
Tabel 7. Karakter fenotipik isolat jamur dan strain acuan

\begin{tabular}{|c|c|c|c|c|c|c|c|}
\hline & Karakter fenotipik & $\begin{array}{c}\text { Aspergillus niger van Tiegh } \\
\text { IFO } 6341\end{array}$ & $\begin{array}{l}\text { Trichoderma viride } \\
\text { CBS } 189.79\end{array}$ & D9 & S11 & K2 & K11 \\
\hline \multirow[t]{8}{*}{1.} & Morfologi miselium : & + & + & + & + & + & + \\
\hline & - Hifa bersekat & + & - & - & - & + & - \\
\hline & - Warna koloni hitam pekat & - & - & + & + & - & - \\
\hline & - Warna koloni coklat kehitaman & & & & & & \\
\hline & - Warna koloni putih kehijauan & - & + & - & - & - & + \\
\hline & Konidiofor tidak bercabang & + & - & + & + & + & - \\
\hline & $\begin{array}{l}\text { - Ujung konidiofor membulat } \\
\text { membentuk vesikula }\end{array}$ & + & - & + & + & + & - \\
\hline & $\begin{array}{l}\text { Konidiofor bercabang } \\
\text { menyerupai piramida }\end{array}$ & - & + & - & - & - & + \\
\hline \multirow[t]{6}{*}{2.} & Morfologi konidia : & + & + & - & - & + & + \\
\hline & Konidia berbentuk bulat & - & - & + & + & - & - \\
\hline & - Konidia berbentuk oval & + & - & + & + & + & - \\
\hline & Dindıng konıdia bergerigi & - & + & - & - & - & + \\
\hline & - Dinding konidia halus & + & - & + & + & + & - \\
\hline & $\begin{array}{l}\text { - Warna konidia coklat } \\
\text { - Warna konidia hijau }\end{array}$ & - & + & - & - & - & + \\
\hline \multirow[t]{3}{*}{3.} & $\begin{array}{l}\text { Asimilasi karbon }(1 \% \mathrm{w} / \mathrm{v}) \text { : } \\
\text { - Fruktosa }\end{array}$ & + & + & + & + & + & + \\
\hline & - Laktosa & + & + & + & + & + & + \\
\hline & - Arabinosa & + & + & + & + & + & + \\
\hline \multirow[t]{2}{*}{4.} & Asimilasi N $(0,2 \% \mathrm{w} / \mathrm{v})$ : & & & & & & \\
\hline & $\begin{array}{l}\cdot \mathrm{NO}_{2}^{-} \\
\mathrm{NO}_{3}^{-}\end{array}$ & + & + & + & + & + & + \\
\hline \multirow[t]{5}{*}{5.} & Kemampuan degradasi : & & & & & & \\
\hline & - Pati & + & + & + & + & + & + \\
\hline & - Selulosa & + & + & + & + & + & + \\
\hline & - Tween-80 & - & + & - & - & - & + \\
\hline & - Kasein & + & + & + & + & + & + \\
\hline
\end{tabular}

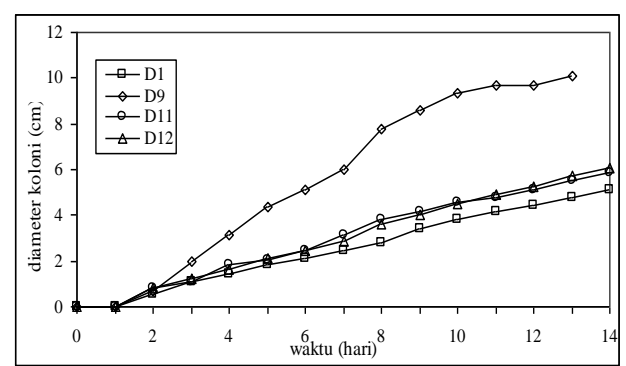

(a)

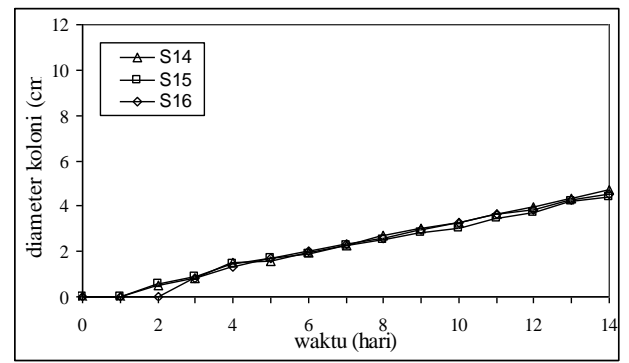

(c)

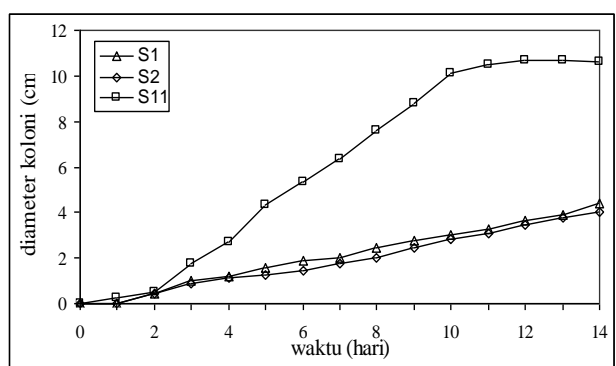

(b)

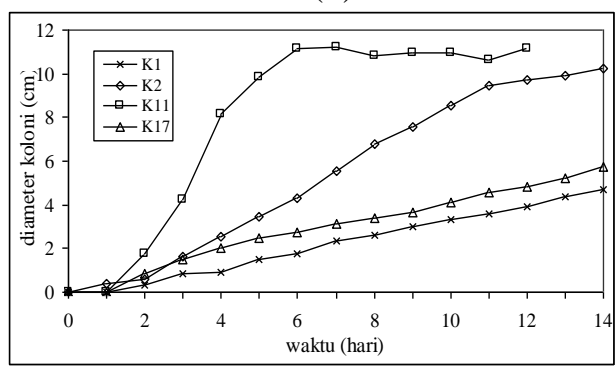

(d)

Gambar 1. Pertumbuhan isolat jamur dalam medium minimal padat yang mengandung 4 mM katekin

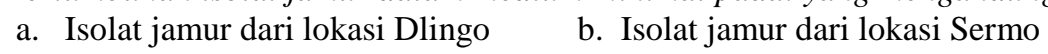


c. Isolat jamur dari lokasi Sermo

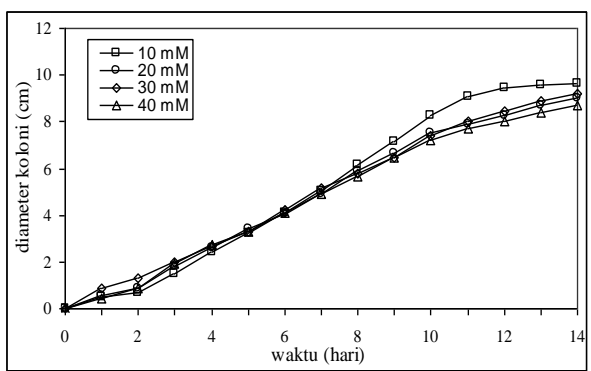

(a)

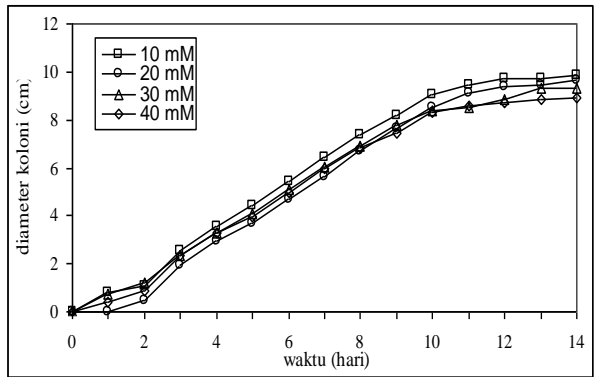

(c) d. Isolat jamur dari lokasi Kalikuning

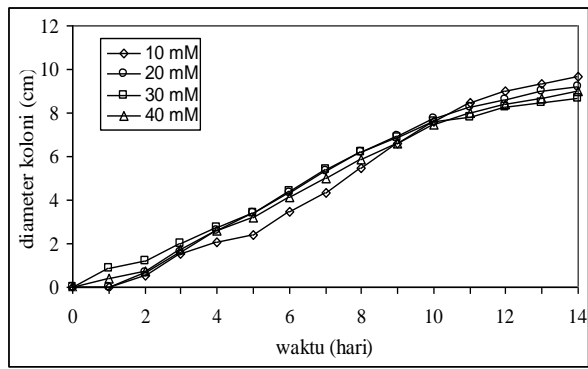

(b)

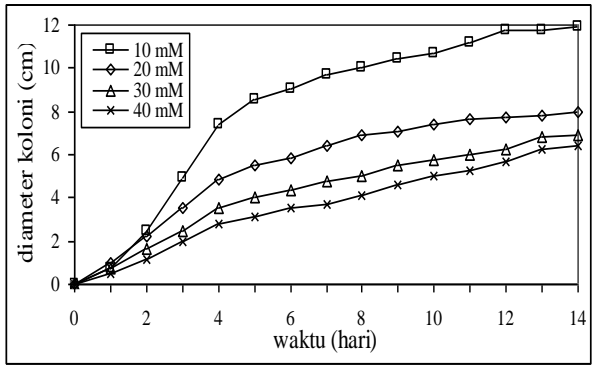

(d)

Gambar 2. Pertumbuhan isolat jamur dalam konsentrasi katekin 10 mM, 20 mM, 30 mM dan 40 mM selama 14 hari (inkubasi suhu kamar).
a. isolat D9
b. isolat S11
c. isolat $K 2$
d. isolat K11

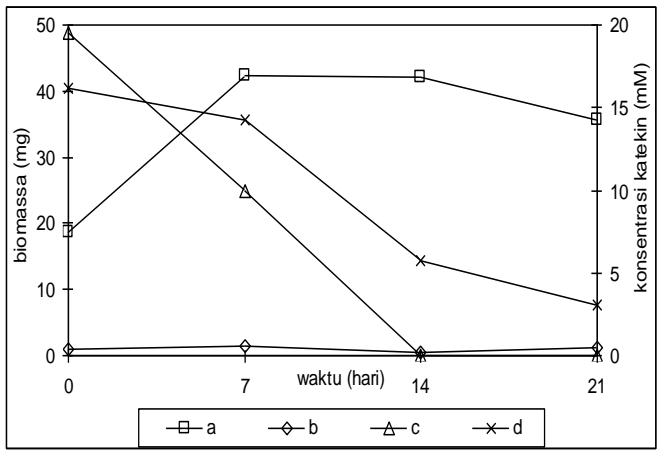

(1)

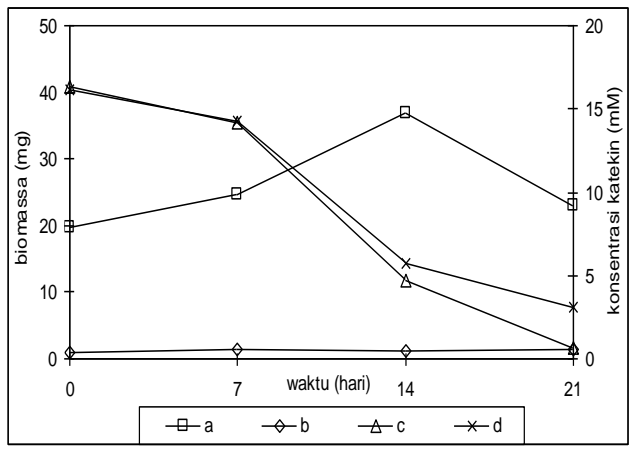

(2)

Gambar 3. Pertumbuhan dan aktivitas biodegradasi katekin oleh isolat K2 dan K11 dalam medium cair dengan konsentrasi katekin $20 \mathrm{mM}$.
1. Isolat $\mathrm{K} 2$
2. Isolat $\mathrm{K} 11$

Keterangan : a. biomassa jamur (mg)

b. biomassa jamur (mg) dalam medium tanpa katekin

c. penurunan konsentrasi katekin $(\mathrm{mM})$ oleh aktivitas jamur

d. penurunan konsentrasi katekin (mM) tanpa inokulasi jamur (kontrol) 
